\title{
Color Change of Different Dual-Cure Resin Cements After Thermocycling
}

\section{Cambio de color de diferentes cementos de resina de curado doble después del termociclaje}

Ayşe Atay DDS, PhD'; Zülal Palazli DDS2; Işıl Gürdal DDS33; Aslıhan Üşümez DDS, PhD ${ }^{4}$

1. Department of Prosthodontics, Faculty of Dentistry, Altinbas University, Istanbul, Turkey.

2. Graduate student, Faculty of Dentistry, Bezmialem Vakif University, Istanbul, Turkey.

3. Department of Prosthodontics, Faculty of Dentistry, Bezmialem Vakif University, Istanbul, Turkey.

4. Private Clinic, Istanbul, Turkey.

Correspondence to: Dr. Ayșe Atay - ayse.atay@altinbas.edu.tr

Received: 20-III-2019

Accepted: 25-III-2019

Published Online First: 29-III-2019

DOI: 10.15517/IJDS.V0I0.36783

\section{ABSTRACT}

The purpose of this study is to evaluate the effect of thermocycling on the color change of the amine-free dual-cure resin cements. IPS e.max CAD blocs were cut into specimens of $1 \mathrm{~mm}$ thickness $(\mathrm{N}=28)$ and cemented with one of the 4 different amine-free dual-cure resin cements (NX3 Nexus [NX], Kerr Dental; Variolink Esthetic DC [VE], Ivoclar Vivadent; Panavia V5 [PV], Kuraray Dental; G-CEM Linkforce [GC], GC Corporation) ( $n=7)$. A spectrophotometer was used for color measurements. Specimens were subjected to thermocycling $\left(5^{\circ} \mathrm{C}\right.$ and $55^{\circ} \mathrm{C} ; 5000$ and 10000 cycles). Normality of data distribution was tested by using the Kolmogorov-Smirnov test. Statistical analysis was performed using a two-way analysis of variance (ANOVA) and Tukey's multiple comparison tests at a significance level of $p<0.05$. $\Delta E$ values were significantly influenced by the resin cements and the cycle periods $(p<0.05)$. There were no significant differences between NX and VE groups after 5000 thermocycling, however after 10000 thermocycling VE group showed higher $\triangle \mathrm{E} 1$ values than $\mathrm{NX}$ group ( $\mathrm{p}>0.05)$. There were no statistically significant differences between the $\triangle \mathrm{E} 0$ and $\triangle \mathrm{E} 1$ values of the $\mathrm{GC}$ group, however the other groups were affected after 10000 thermocycling ( $p>0.05$ ). Amine-free resin cements used for cementation showed color change after thermocycling except GC group. All resin cements were showed clinically acceptable color change after thermocycling $(\Delta \mathrm{E}<3.5)$.

\section{KEYWORDS}

Resin cements; Prosthesis Coloring; Aging. 


\section{RESUMEN}

El propósito de este estudio es evaluar el efecto del termociclaje en el cambio de color de los cementos de resina de doble curado sin aminas. Los bloques IPS e.max CAD se cortaron en muestras de $1 \mathrm{~mm}$ de espesor $(\mathrm{N}=28)$ y se cementaron con uno de los 4 diferentes cementos de resina de curado doble libres de aminas (NX3 Nexus [NX], Kerr Dental; Variolink Esthetic DC [VE], Ivoclar Vivadent; Panavia V5 [PV], Kuraray Dental; G-CEM Linkforce [GC], GC Corporation) ( $n=7)$. Se usó un espectrofotómetro para las mediciones de color. Las muestras se sometieron a termociclaje $\left(5^{\circ} \mathrm{C}\right.$ y $55^{\circ} \mathrm{C} ; 5000$ y 10000 ciclos). La normalidad de la distribución de datos se probó utilizando la prueba de Kolmogorov-Smirnov. El análisis estadístico se realizó mediante un análisis de varianza de dos vías (ANOVA) y las pruebas de comparación múltiple de Tukey a un nivel de significación de $p<0.05$. Los valores de $\Delta E$ fueron significativamente influenciados por los cementos de resina y los períodos de ciclo $(p<0.05)$. No hubo diferencias significativas entre los grupos NX y VE después de 5000 termociclos, sin embargo, después de 10000, el grupo VE mostró valores $\triangle E 1$ mayores que el grupo NX ( $p>0.05)$. No hubo diferencias estadísticamente significativas entre los valoresn $\triangle \mathrm{E} 0$ y $\triangle \mathrm{E} 1$ del grupo $\mathrm{GC}$, no obstante, los otros grupos se vieron afectados después de 10000 termociclos ( $p>0.05)$. Cementos de resina libres de aminas. utilizados para la cementación mostró cambio de color después del termociclaje, excepto el grupo GC. Todos los cementos de resina mostraron un cambio de color clínicamente aceptable después del termociclaje $(\Delta \mathrm{E}<3.5)$.

\section{PALABRAS CLAVE}

Cementos de resina; Prótesis para colorear; Envejecimiento.

\section{INTRODUCTION}

All-ceramic restorations have become a popular choice for anterior restorations due to their superior aesthetic properties (1). All-ceramic materials can reflect the natural appearance of the teeth, and their optical properties are very similar to dental tissues (2). Conservative preparation techniques help clinicians produce thinner restorations with higher translucency $(3,4)$. Many factors such as the type of the luting cement, the color of the restoration material, and the color of the tooth itself can affect the final shade of restorations (5). Therefore, determining the final color of the restorations can be difficult. Resin cements should preserve their color properties over the long-term for successful restorations (6).

All-ceramic restorations are usually cemented with resin cements, which provide satisfying aesthetics, low solubility in the oral environment, and superior mechanical properties and bond strength (7). Various cements (dual or light cure) with different cementing processes are needed for specific types of restorations. Because of low penetration of polymerization light, dual-cure resin cements are used for thicker restorations (8). Resin cements change in color in the oral environment because of extrinsic or intrinsic factors (9). The oxidation of unreacted double bonds and the resulting products from the degradation of resin after water absorption cause intrinsic color changes $(10,11)$. Dual-cure resin cements contain camphorquinone, peroxide, and aromatic tertiary amines as polymerization initiators. Dual-cure resin cements have many advantages, such as superior aesthetic properties due to their different color and opacity options, low solubility in oral fluids, superior mechanical properties compared to conventional cements, high radiopacity and bond strength to 
dental tissues, and increased durability. Due to these properties, they are recommended for use in cementation of all-ceramic crowns, bridges, laminate veneers, inlays, onlays, fiber or ceramic posts, adhesive bridges, and implant supported restorations $(6,7,12,13)$. The aromatic amine accelerators and inhibitors are the main cause of color change, which is the greatest disadvantage of these cements. These amine molecules go through oxidation reactions that result in color changes in the resin $(6,7)$. All amines produce by-products, which are formed during polymerization and cause a color change from yellow to brown over time. The aliphatic amines used in light curing systems are more color stable than the aromatic amines used in chemical curing systems (14). Previous studies have shown that the new systems without benzoyl peroxide/amine redox initiators result in less color change (15). Even the fully polymerized resins present a clinical color change over time. This is due to the intrinsic factors that cause alterations in chemical structures $(16,17)$.

The resin cements evaluated in this study do not contain the amine compounds that play an important role in the coloring of resin materials. There are limited studies on amine-free resin cement materials in the literature. The purpose of the present study was to evaluate the effect of aminefree dual-cure resin cements on the color of allceramic CAD/CAM materials before and after thermocycling. The hypothesis of this study is that different adhesive material types do not affect the color values of restorations, and thermocycling does not have any effect on the final color of any of the materials tested.

\section{MATERIALS AND METHODS}

The ceramic samples (A2 HT-colored IPS e. max CAD, IvoclarVivadent, Schaan, Liechtenstein) cemented with one of 4 different dual-cure resin cements were tested in this study and are detailed in Table 1. The tested ceramic blocs were cut under water cooling (Mecatome T180, Presi, Grenoble, France) into rectangular specimens $12 \mathrm{~mm}$ in width, $14 \mathrm{~mm}$ in length, and $1 \mathrm{~mm}$ in thickness. A total of 28 specimens ( $n=7$ per test material) were produced. The crystallization process was conducted according to the manufacturer's recommendations. The ceramic samples were polished with P600, P1200, and P2000 SiC sheets on one side. The thicknesses of the specimens were reduced to $1 \pm 0.05 \mathrm{~mm}$, and they were checked with a digital caliper. Each specimen was ultrasonically cleaned before cementation. The bonding surfaces of the ceramic specimens were etched with 9.5\% hydrofluoric acid (Porcelain Etch; Ultradent Products, Inc.) for 20 seconds. After acid etching, the samples were rinsed with pressurized water and dried using an air spray. For each cement group, the manufacturer's recommended ceramic primers were applied to the ceramic surfaces for 60 seconds and dried with dry air. The resin cements were placed under specimens, and a glass slide was placed on top of each specimen without any weight. The mean thickness of the cement was $0.15 \pm 0.05 \mathrm{~mm}$ for all specimens. A light-emitting diode unit (Valo, Ultradent, South Jordan) with an intensity of $1200 \mathrm{~mW} / \mathrm{cm} 2$ was used for 10 seconds to achieve polymerization. A spectrophotometer (VITA Easyshade Advance, VITA Zahnfabrik, Bad Säckingen, Germany) was used for color measurements. Spectrophotometric measurements were made under light-proof conditions with a white background under the specimens. The measurements were repeated 3 times for each specimen, and the spectrophotometer was calibrated after each measurement. The specimens were then thermocycled (Thermocycler, SD Mechatronik, Germany) in distilled water between 5 and $55^{\circ} \mathrm{C}$ for 5,000 and 10,000 cycles. The International Commission on Illumination (CIELab system) was used to measure mean $L^{*}, a^{*}$, and $b^{*}$ values. After thermocycling, color measurements were repeated, and CIELab values were recorded to be used in the following $\Delta \mathrm{E}$ formula: $\Delta \mathrm{E}=\left[\left(\Delta \mathrm{L}^{*}\right)^{2}+\left(\Delta \mathrm{a}^{*}\right)^{2}+\left(\Delta \mathrm{b}^{*}\right)^{2}\right]^{1 / 2}$. The 
$\Delta \mathrm{E}$ formula was used to calculate the difference between the color values after 5,000 cycles and 10,000 cycles. The collected data were analyzed with statistical software (IBM SPSS Statistics v22.0; IBM Corp). A power analysis with an estimated power of $80 \%$ and $\alpha=0.05$ significance level was conducted on the $\Delta E$ values to determine the number of samples $(n=7)$. The normality of the data distribution was tested with the KolmogorovSmirnov test. The data were statistically analyzed using two-way ANOVA, and the Tukey-HSD post hoc test. In all tests, $p<0.05$ was considered significant.

Table 1. The brand names, abbreviations, resin shades, lot numbers, material compositions and manufacturers of the materials used in the study.

\begin{tabular}{|c|c|c|c|c|c|}
\hline Resin Cement & Abbr. & $\begin{array}{l}\text { Resin } \\
\text { Shade }\end{array}$ & Lot No & Composition (Filler Content) & Manufacturer \\
\hline Variolink Esthetic DC & VE & Neutral & V20176 & $\begin{array}{l}\text { Monomer matrix: UDMA, } \\
\text { inorganic fillers (ytterbium } \\
\text { trifluoride and spheroid mixed } \\
\text { oxide), initiators, stabilizers, } \\
\text { pigments }\end{array}$ & $\begin{array}{l}\text { Ivoclar Vivadent, } \\
\text { Schaan, Liechtenstein }\end{array}$ \\
\hline Panavia V5 & PV & Clear & AJ0009 & $\begin{array}{l}\text { Bis-GMA, TEGDMA, } \\
\text { hydrophobic aromatic } \\
\text { dimethacrylate, hydrophilic } \\
\text { aliphatic dimethacrylate, } \\
\text { barium glass filler, } \\
\text { fluoroaluminosilicate } \\
\text { glass, silica filler, initiators, } \\
\text { stabilizers, pigments ( } 61.0 \\
\text { wt\%, } 38.0 \text { vol\%) }\end{array}$ & $\begin{array}{l}\text { Kuraray Noritake } \\
\text { Dental, Okayama Japan }\end{array}$ \\
\hline NX3 Nexus & NX & Clear & 5878470 & $\begin{array}{l}\text { Methacrylate ester monomer, } \\
\text { mineral fillers, initiators, } \\
\text { stabilizers, pigments, } \\
\text { radiopaque agent ( } 66.5 \mathrm{wt} \% \text {, } \\
43.3 \text { vol\%) }\end{array}$ & $\begin{array}{l}\text { Kerr Dental, } \\
\text { California, America }\end{array}$ \\
\hline G-CEM Linkforce & GC & Translucent & 1608221 & $\begin{array}{l}\text { Dimethacrylate, silica filler, } \\
\text { initiators, stabilizers, pigments } \\
\text { (63.0 wt\%, } 38.0 \text { vol\%) }\end{array}$ & $\begin{array}{l}\text { GC Corporation, } \\
\text { Tokyo, Japan }\end{array}$ \\
\hline
\end{tabular}

Abbreviations: UDMA: urethane dimethacrylate; Bis-GMA: bisphenol A-glycidyl methacrylate; TEGDMA: triethylene glycol dimethacrylate. 


\section{RESULTS}

Two-way ANOVA revealed statistically significant differences in the $\Delta \mathrm{E}$ values among the resin cement materials and between the cycle periods $(p<0.05)$. There were interactions among the materials and the cycle periods $(p<0.05)$ (Table 2).

The $\Delta \mathrm{E}$ values for the color before and after 5,000 thermal cycles $\left(\Delta E_{1}\right)$ and before and after 10,000 thermal cycles $\left(\Delta \mathrm{E}_{2}\right)$ are given in Table 3. The $\Delta \mathrm{E}_{1}$ value of the $\mathrm{NX}$ group was statistically significantly lower than that of the PV and GC groups $(p<0.05)$, but the differences between the $\mathrm{NX}$ and VE groups were not statistically significant $(p>0.05)$.

When $\Delta \mathrm{E}_{2}$ values were compared among the materials, the differences between the VE and the NX groups were statistically significant $(p<0.05)$; however, there were no significant differences among the other materials.

When the effects of thermocycling on the color values were evaluated, there was no statistically significant difference between the $\Delta \mathrm{E}_{1}$ and $\Delta \mathrm{E}_{2}$ values of the GC group ( $p>0.05)$. However, the differences between the $\Delta \mathrm{E}_{1}$ and $\Delta \mathrm{E}_{2}$ values of the $\mathrm{VE}, \mathrm{PV}$, and $\mathrm{NX}$ groups were statistically significant $(p<0.05)$.

When the effect of thermocycling on the $\Delta \mathrm{L}$ values was examined (Table 4 ), a statistically significant difference was observed in the measured $\mathrm{L}^{*}$ value before and after 5,000 $\left(\mathrm{L}_{1}^{*}\right)$ and $10,000\left(\mathrm{~L}^{\star}\right)$ thermocycles in all tested material groups $(p<0.05)$. The $L^{*}$ values decreased after thermocycling in all tested material groups $(p<0.05)$.

When the effects of thermocycling on $\Delta b$ values were examined (Table 5) in the PV group, the $b_{2}{ }^{*}$ value was lower than the $b_{1}{ }^{*}$ and $b_{0}{ }^{*}$ values $(p<0.05)$. In the NX group, the difference between the $b_{0}{ }^{*}$ and $b_{2}{ }^{*}$ values was statistically significant $(p<0.05)$, and in the GC group, there were statistically significant differences among the $b 0^{*}, b 1^{*}$, and $b 2^{*}$ values $(p<0.05)$.

When the effect of thermocycling on $\Delta \mathrm{a}$ values was examined (Table 6) in the VE group, there were statistically significant differences between the values obtained before $\left(\mathrm{a}^{*}\right)$ and after 5,000 $\left(\mathrm{a} 1^{*}\right)$ and $10,000\left(\mathrm{a} 2^{*}\right)$ thermocycles $(\mathrm{p}<0.05)$. 
Table 2. Two way analysis of variance of $\Delta E$ values.

\begin{tabular}{lccccc}
\hline & Sum of Squares & df & Mean Square & F & Sig. \\
\hline Materials & 7.775 & 3 & 2.592 & 16.893 & .000 \\
Cycle periods & 12.826 & 1 & 12.826 & 83.597 & .000 \\
Materials * Cycle periods & 3.960 & 3 & 1.320 & 8.605 & .000 \\
\hline
\end{tabular}

Table 3. Descriptive statistics for $\Delta \mathrm{E} 1$ and $\Delta \mathrm{E}_{2}$ values of all tested material groups.

\begin{tabular}{ccc}
\hline Adhesive resin cement & $\boldsymbol{\Delta E} 1$ (Mean \pm SD) & $\Delta \mathrm{E} 2$ (Mean \pm SD) \\
\hline VE & $1.27 \pm 0.34 \mathrm{Aab}$ & $3.08 \pm 0.50^{\mathrm{Ba}}$ \\
PV & $1.55 \pm 0.30^{\mathrm{Aa}}$ & $2.47 \pm 0.46^{\mathrm{Bab}}$ \\
NX & $0.84 \pm 0.26^{\mathrm{Ab}}$ & $1.55 \pm 0.29^{\mathrm{Bb}}$ \\
GC & $1.69 \pm 0.38^{\mathrm{Aa}}$ & $2.07 \pm 0.55^{\mathrm{Aab}}$ \\
\hline
\end{tabular}

*Lower case superscripts correspond the same column, capital superscripts correspond the same line.

*Significantly different at $p<0.05$.

Table 4. Descriptive statistics for $L_{0}{ }^{*}, L_{1}{ }^{*}$ and $L_{2}{ }^{*}$ values of all tested materials.

\begin{tabular}{|c|c|c|c|}
\hline Adhesive resin cement & L0* $^{\star}($ Mean $\pm S D)$ & $\mathrm{L1}^{*}($ Mean $\pm \mathrm{SD})$ & $\mathrm{L}^{\star}{ }^{\star}($ Mean $\pm \mathrm{SD})$ \\
\hline VE & $96.68 \pm 0.32^{\mathrm{A}}$ & $95.70 \pm 0.73^{\text {в }}$ & $93.78 \pm 0.76^{c}$ \\
\hline PV & $94.86 \pm 1.22^{\mathrm{A}}$ & $93.89 \pm 0.99$ в & $92.87 \pm 1.16^{c}$ \\
\hline NX & $93.19 \pm 1.01^{\mathrm{A}}$ & $92.65 \pm 0.98^{\text {в }}$ & $91.79 \pm 0.93^{c}$ \\
\hline GC & $94.78 \pm 0.97 \mathrm{~A}$ & $93.56 \pm 0.71^{\mathrm{B}}$ & $92.78 \pm 0.82^{c}$ \\
\hline
\end{tabular}

${ }^{*}$ Capital case superscripts correspond the same line.

${ }^{*}$ Significantly different at $p<0.05$.

Table 5. Descriptive statistics for $b_{0}{ }^{*}, b_{1}{ }^{*}$ and $b_{2}{ }^{*}$ values of all tested material groups.

\begin{tabular}{cccc}
\hline Adhesive resin cement & b0* $^{*}$ Mean \pm SD) & b1 $^{*}($ Mean \pm SD) & b2* $^{*}$ Mean \pm SD) \\
\hline VE & $12.41 \pm 0.51^{\mathrm{A}}$ & $12.80 \pm 0.83^{\mathrm{A}}$ & $12.31 \pm 0.60^{\mathrm{A}}$ \\
PV & $14.29 \pm 0.86^{\mathrm{A}}$ & $14.33 \pm 1.21^{\mathrm{A}}$ & $13.34 \pm 1.04^{\mathrm{B}}$ \\
NX & $12.49 \pm 0.51^{\mathrm{A}}$ & $12.55 \pm 0.33^{\mathrm{AB}}$ & $12.08 \pm 0.55^{\mathrm{B}}$ \\
GC & $13.05 \pm 0.46^{\mathrm{A}}$ & $13.89 \pm 0.81^{\mathrm{B}}$ & $13.02 \pm 0.45^{\mathrm{A}}$ \\
\hline
\end{tabular}

${ }^{*}$ Capital case superscripts correspond the same line.

${ }^{*}$ Significantly different at $p<0.05$. 
Table 6. Descriptive statistics for $\mathrm{a}^{*}, \mathrm{a}^{*}$ and $\mathrm{a}^{*}$ values of all tested material groups.

\begin{tabular}{|c|c|c|c|}
\hline Adhesive resin cement & $\mathrm{a}^{*}($ Mean $\pm \mathrm{SD})$ & a1* $($ Mean $\pm S D)$ & $\mathrm{a}^{*}$ (Mean $\left.\pm \mathrm{SD}\right)$ \\
\hline VE & $-1.84 \pm 0.10^{\mathrm{A}}$ & $-1.44 \pm 0.19^{\text {в }}$ & $-0.97 \pm 0.23^{c}$ \\
\hline PV & $-1.79 \pm 0.29 \mathrm{~A}$ & $-1.45 \pm 0.29^{\mathrm{B}}$ & $-1.31 \pm 0.31^{\text {в }}$ \\
\hline NX & $-1.49 \pm 0.14^{\mathrm{A}}$ & $-1.22 \pm 0.34^{\mathrm{B}}$ & $-1.05 \pm 0.23^{\mathrm{B}}$ \\
\hline GC & $-1.75 \pm 0.21^{\mathrm{A}}$ & $-1.35 \pm 0.20^{\mathrm{B}}$ & $-1.45 \pm 0.19^{в}$ \\
\hline
\end{tabular}

${ }^{*}$ Capital case superscripts correspond the same line.

*Significantly different at $p<0.05$.

\section{DISCUSSION}

The results of this in vitro study revealed that material type and thermocycling have a significant effect on color values. Therefore, the null hypotheses that different resin cement material types do not affect the color values of the restorations, and thermocycling does not have any effect on the final color of all materials tested were rejected.

Resin cements are preferred in the cementation of full ceramic restorations. Dual-cure adhesive resin cements have become widely used in the cementation of ceramic crowns, inlays, onlays, and lamina restorations $(13,19,20)$. Resin cements are not only used for cementation of restorations but also for final color construction (21). Studies have shown that the final color of ceramic restorations is not only determined by the color of the ceramic material but also by the color of the resin cement. It has also been reported that restoration and cement thickness, ceramic type, and underlying dentine color can affect color $(18,22-24)$. In this study, the effects of 4 different amine-free dualcure resin cements on the color of all-ceramic CAD/CAM materials before and after 5,000 and 10,000 thermocycles were investigated.

The resin cements used in this study do not contain amine compounds, which play an important role in the final color of restorations, and these resin cements are especially recommended for the cementation of aesthetic restorations. There has been insufficient research on these materials $(25,26)$.

Polymerization of dual polymerized resin compounds is influenced by the color of restoration and resin materials (27). Thus, a clear color adhesive material and an A2 HT-colored ceramic material were chosen to provide standardization in this study.

In order to assess the clinical performance of dental materials, laboratory conditions should mimic oral conditions; therefore, materials are subjected to various thermocycling methods in dental research. The thermocycling process is one of these methods, and it reflects intraoral conditions by subjecting the samples to moisture via heat exchange $(28,29)$. In the current study, specimens were subjected to 5,000 and 10,000 thermocycles.

The $L, a$, and $b$ values of the tested specimens were affected by the material and cycle periods. In addition, there were significant differences in the $\Delta E$ values across different materials, cycle periods, and cement types $(p=.000)$. The $\Delta E$ values were found to be at or under the clinically perceptible threshold ( $\triangle \mathrm{E} 2$ to 3.5) stated by O'Brien et al. (30) in all the tested resin cement groups. 
Almeida et al. (29) revealed that the color change after the thermocycling in dual-cure resin cements were higher than the light-cure resin cements. This result was based on the oxidation of amine molecules that react with benzoyl peroxide in dual-cure systems (29). Amine-free resin cements were tested in the present study, and recent studies have shown that the resin cements containing the amine-free initiator system have better color stability and less discoloration $(25,26)$. The NX group showed the lower $\triangle E$ values than the PV and GC groups after 5,000 thermocycles, but there was no significant difference between the NX and VE groups. This may be due to the fact that the VE group contains Ivocerin, which was developed as an alternative to camphorquinone and does not require amine molecules to initiate the reaction. However, after 10,000 thermocycles, there was a significant difference between the NX and VE groups. The VE group showed an increased $\triangle \mathrm{E} 1$ value $(3.08 \pm 0.50)$ after 10,000 thermocycles. The $\triangle \mathrm{E}$ values of the GC group were not affected by thermocycling.

According to the results of the present study, there were differing $\Delta \mathrm{E}$ values among the resin cements. This may be due to the differences in the chemical composition of the cements, their degree of polymerization, and their tendency to water absorption $(29,31,32)$. In addition, the hydroxyl and ester groups of the Bis-GMA molecules contained in some resin cements absorb water and are susceptible to hydrolysis. These hydrolytic and hygroscopic effects have been reported to play an important role in the color changes of resin-based materials (33).

Changes in $L^{*}$ (change of brightness) values are important for the long-term color stability of restorations. According to the results of this study, $L^{*}$ values were affected by the cycle periods.
The $L^{*}$ values of all materials decreased after 5,000 and 10,000 thermocycles. This result is in accordance with those of previous studies, in which the $L^{*}$ values of resin materials were found to decrease after thermocycling $(29,31)$. The $a^{*}$ (change of redness/greenness) values of all materials increased after 5,000 thermocycles. After 10,000 thermocycles only a* values of VE group increased. Sabatini et al. (34) observed the color changes 24 hours after polymerization and they stated that the continued polymerization causes changes in color. $19-26 \%$ of the total polymerization of resin materials has been identified as post-irradiation polymerization (35). On the contrary, in the present study thermocycles did not cause an increase in $b^{*}$ values in all groups and this shows that the polymerization did not continue after the initial spectrophotometric measurements.

The present study has some limitations. The color measurement was performed as soon as the specimens were cemented. Blatz et al. (21) reported that the time required for the completion of polymerization is approximately 24 hours in areas where the light cannot reach sufficiently in dual-curing resin cements. To improve the clinical relevance of the findings of the present study, future investigations should be performed using the tooth surface as a background instead of using a white background. Future investigations might be performed using different resin cements, CAD/ CAM materials, and different CAD/CAM material thicknesses.

\section{CONCLUSION}

Within the limitation of this in vitro study, the following conclusions were drawn:

- Thermocycling and types of resin cements may affect the color stability. 
- The color changes resin cements after thermocycling were within clinically acceptable limits $(\Delta \mathrm{E}<3.5)$.

- NX resin cement group showed the lowest color change after 5,000 and 10,000 thermocycles.

- The $\Delta \mathrm{E} 1$ and $\Delta \mathrm{E} 2$ values of the all amin-free adhesive resin cement groups showed significant changes, except for G-CEM Linkforce group.

\section{REFERENCES}

1. Kilinc E., Antonson S. A., Hardigan P. C., Kesercioglu A. Resin cement color stability and its influence on the final shade of allceramics. J Dent. 2011; 39: 30-36.

2. Azer S. S., Rosenstiel S. F., Seghi R. R., Johnston W. M. Effect of substrate shades on the color of ceramic laminate veneers. J Prosthet Dent. 2011; 106 (3): 179-183.

3. Heffernan M. J., Aquilino S. A., Diaz-Arnold A. M., Haselton D. R., Stanford C. M., Vargas M. A. Relative translucency of six allceramic systems. Part II. Core and veneer materials. J Prosthet Dent. 2002; 88: 10-15.

4. Nathanson D., Banasr F. Color stability of resin cements - an in vitro study. Pract Proced Aesthetic Dent. 2002; 14: 449-455; quiz 456.

5. Charisis D., Koutayas S. O., Kamposiora P., Doukoudakis A. Spectrophotometric evaluation of the influence of different backgrounds on the color of glass-infiltrated ceramic veneers. Eur J Esthet Dent. 2006; 1: 142-156.

6. Kilinc E., Antonson S. A., Hardigan P. C., Kesercioglu A. Resin cement color stability and its influence on the final shade of allceramics. J Dent. 2011; 39: 30-36.

7. Rosenstiel S. F., Land M. F., Crispin B. J. Dental luting agents: a review of the current literature. J Prosthet Dent.1998; 80: 280-301.
8. Haddad M. F., Rocha E. P., Assunção W. G. Cementation of prosthetic restorations: from conventional cementation to dental bonding concept. J Craniofac Surg. 2011; 22: 952-958.

9. Hosoya Y. Five-year color changes of lightcured resin composites: Influence of light-curing times. Dent Mater. 1999; 15 (4): 268-274.

10. Arocha M. A., Mayoral J. R., Lefever D., Mercade M., Basilio J., Roig M. () Color stability of siloranes versus methacrylate- based composites after immersion in staining solutions. Clin Oral Investig. 2013; 17: 1481-1487.

11. Falkensammer F., Arnetzl G. V., Wildburger A., Freudenthaler J. Color stability of different composite resin materials. J Prosthet Dent. 2013; 109: 378-383.

12. Hill E. E., Lott J. A clinically focused discussion of luting materials. Aust Dent J. 2011; 56 (1): 67-76.

13. Pegoraro T. A., da Silva N. R., Carvalho R. M. Cements for use in esthetic dentistry. Dent Clin North Am. 2007; 51 (2): 453-471.

14. Asmussen E. Factors affecting the colour stability of restorative resins. Acta Odontol Scand. 1983; 41 (1): 11-18.

15. Smith D. S., Vandewalle K. S., Whisler G. Color stability of composite resin cements. Gen Dent. 2011; 59: 390-394.

16. Malekipour M. R., Sharafi A., Kazemi S., Khazaei S., Shirani F. Comparison of color stability of a composite resin in different color media. Dent Res J. (Isfahan) 2012; 9: 441-446.

17. Wang F., Takahashi H., Iwasaki N. Translucency of dental ceramics with different thicknesses. J Prosthet Dent. 2013; 110: 14-20.

18. Lu H., Powers J. M. Color stability of resin cements after accelerated aging. Am J Dent. 2004; 17 (5): 354-358. 
19. Usumez A., Ozturk A. N., Usumez S., Ozturk B. The efficiency of different light sources to polymerize resin cement beneath porcelain laminate veneers. J Oral Rehabil. 2004; 31 (2): 160-165.

20. Blackman R., Barghi N., Duke E. Influence of ceramic thickness on the polymerization of light-cured resin cement. J Prosthet Dent. 1990; 63 (3): 295-300.

21. Blatz M. B., Sadan A., Kern M. Resinceramic bonding: a review of the literature. J Prosthet Dent. 2003; 89 (3): 268-274.

22. Raptis N. V., Michalakis K. X., Hirayama H. Optical behavior of current ceramic systems. Int J Periodontics Restorative Dent. 2006; 26 (1): 31-41.

23. Vichi A., Ferrari M., Davidson C. L. Influence of ceramic and cement thickness on the masking of various types of opaque posts. J Prosthet Dent. 2000; 83 (4): 412-417.

24. Koishi Y., Tanoue N., Atsuta M., Matsumura $\mathrm{H}$. Influence of visible-light exposure on colour stability of current dual-curable luting composites. J Oral Rehabil. 2002; 29 (4): 387-393.

25. Ural Ç., Duran İ., Tatar N., Öztürk Ö., Kaya I., Kavut I. The effect of amine-free initiator system and the polymerization type on color stability of resin cements. J Oral Sci. 2016; 58 (2): 157-161.

26. Gürdal I., Atay A., Eichberger M., Cal E., Üsümez A., Stawarczyk B. Color change of CAD-CAM materials and composite resin cements after thermocycling. J Prosthet Dent. 2018; 120 (4): 546-552.

27. Öztürk E., Bolay Ş., Hickel R., Ilie N. Effects of ceramic shade and thickness on the micro- mechanical properties of a light-cured resin cement in different shades. Acta Odontol Scand. 2015; 73 (7): 503-507.

28. Al-Harbi F. A., Ayad N. M., ArRejaie A. S., Bahgat H. A., Baba N. Z. Effect of aging regimens on resin nanoceramic chairside CAD/CAM material. J Prosthodont. 2017; 26 (5): 432-439.

29. Almeida J. R., Schmitt G. U., Kaizer M. R., Boscato N., Moraes R. R. Resin-based luting agents and color stability of bonded ceramic veneers. J Prosthet Dent. 2015; 114 (2): 272-277.

30. O’Brien W. J., Kay K. S., Boenke K. M., Groh C. L. Sources of color variation on firing porcelain. Dent Mater. 1991; 7 (3): 170-173.

31. Archegas L. R., Freire A., Vieira S., Caldas DB, Souza EM. Colour stability and opacity of resin cements and flowable composites for ceramic veneer luting after accelerated ageing. J Dent. 2011; 39 (11): 804-810.

32. Silami F. D., Tonani R., Alandia-Román C. C., Pires-de-Souza Fde C. Influence of different types of resin luting agents on color stability of ceramic laminate veneers subjected to accelerated artificial aging. Braz Dent J. 2016; 27 (1): 95-100.

33. Ferracane J. L. Hygroscopic and hydrolytic effects in dental polymer networks. Dent Mater. 2006; 22 (3): 211-22.

34. Sabatini C., Campillo M., Aref J. Color stability of ten resin-based restorative materials. J Esthet Restor Dent. 2012; 24 (3): 185-199.

35. Halvorson R. H., Erickson R. L., Davidson C. L. Energy dependent polymerization of resin-based composite. Dent Mater. 2002; 18 (6): 463-469. 